\title{
Biomineralization of Zinc-Phosphate-Based Nano Needles by Living Microalgae
}

\author{
Giulia Santomauro $^{1 *}$, Vesna Srot ${ }^{2}$, Birgit Bussmann², Peter A. van Aken², Franz Brümmer ${ }^{3}$, \\ Horst Strunk $^{1}$, Joachim Bill ${ }^{1}$ \\ ${ }^{1}$ Institute for Materials Science, University of Stuttgart, Stuttgart, Germany; ${ }^{2}$ Stuttgart Center for Electron Microscopy-StEM, Max \\ Planck Institute for Intelligent Systems, Stuttgart, Germany; ${ }^{3}$ Department of Zoology, Institute for Biology, University of Stuttgart, \\ Stuttgart, Germany. \\ Email: *giulia.santomauro@imw.uni-stuttgart.de
}

Received April 24 $4^{\text {th }}, 2012$; revised May 25 ${ }^{\text {th }}, 2012$; accepted June $9^{\text {th }}, 2012$

\begin{abstract}
Up to now, chemical synthesis routes only provide restricted opportunities for the formation of structured nano particles. In contrast, living microorganisms generate nano materials of well defined shapes by the precise control of biomineralization. Here we reveal new principles for the generation of functional nano materials through the process of biomineralization. We used the detoxification mechanism of the unicellular alga Scenedesmus obliquus to generate a technologically interesting zinc-phosphate-based nano material. The algae were incubated in media with a sublethal zinc concentration $\left(6.53 \mathrm{mg} \mathrm{Zn} \mathrm{dm}{ }^{-3}\right)$ for 4 weeks. Using BF- and ADF-STEM imaging combined with analytical XEDS we could show that nano needles containing phosphorus and zinc were formed inside the living cells. Furthermore, the cells incubated with zinc show a strong fluorescence. Our findings indicate that the algae used polyphosphate bodies for detoxification of the zinc ions, leading to the generation of intracellular zinc-phosphate-based nano needles. Beside the technological application of this material, the fluorescent cells can be used for labeling of e.g. biological probes. This new experimental protocol for the production of an inorganic functional material can be applied also for other substances.
\end{abstract}

Keywords: Nano Needles; Biomineralization; Zinc Phosphate; Microalgae; Fluorescence

\section{Introduction}

Due to their broad potential, nano materials are of growing interest for technological applications. Zinc phosphate nano particles can be used as corrosion inhibitors or as dental cement and hydrogelated zinc ultraphosphate glass powders serve for proton-conducting materials [1]. $\mathrm{Zn}_{3}\left(\mathrm{PO}_{4}\right)_{2}$ serves as a host-lattice for fluorescent materials like $\mathrm{Zn}_{3}\left(\mathrm{PO}_{4}\right)_{2}: \mathrm{Eu}$ [2]. Through chemical synthesis, nano materials are produced with high efforts in terms of high temperature or process engineering, e.g. spherical $\mathrm{Zn}_{3}\left(\mathrm{PO}_{4}\right)_{2}$ nano particles can be synthesized via a polyolmediated method at temperatures of $230^{\circ} \mathrm{C}$ or an ultrasonic-microwave route [3,4]. Preparation of $\mathrm{Zn}_{3}\left(\mathrm{PO}_{4}\right)_{2}$ at room temperature resulted in highly aggregated spherical or sheet-like particles $[5,6]$. When yeast cells are used as catalytic templates, butterfly-like particles or agglomerates of $\mathrm{Zn}_{3}\left(\mathrm{PO}_{4}\right)_{2}$ are chemically precipitated on the negatively charged surface of the yeast $[7,8]$. According to that, chemical synthesis routes only provide restricted opportunities for the generation of such inorganic solids

\footnotetext{
${ }^{*}$ Corresponding author.
}

with defined shape. In contrast to chemical synthesis, living organisms are capable of producing highly structured nano particles by the precise control of the biomineralization processes [9]. e.g. sponge primmorphs are capable of the incorporation of titania into their nanospicules when incubated in an appropriate medium [10]. Due to the genetic control of the biomineralization, they react to a certain environment in always the same way, resulting in the reproducible synthesis of nano particles of a certain size and morphology. Since these processes proceed at ambient conditions, nano materials produced by microorganisms are very cost-effective and ecofriendly. When confronted to toxic elements in their environment, microorganisms like algae can sequester them inside their cells in order to detoxify their surrounding. The intracellular sequestration of the toxic metal ions occurs via chelate formation with molecules like phytochelatins or phosphates of different chain length, resulting in metal/phytochelatin or metal/(poly) phosphate complexes which are no more harmful to the organisms $[11,12]$. It is known, that the metal ions first bind on the cell wall of the algae to specific transport ligands as well 
as to inert adsorption sites [13,14]. The cell walls of green algae consist of polysaccharides and proteins and contain also polyphosphates [15-17]. In the following step, some of the metal ions are actively transported into the interior of the cell, where they can build complexes with polyphosphates $[18,19]$. In this study, we used this detoxification mechanism of a unicellular green alga species (Chlorophyceae) to generate structured zinc-phosphate-based nano particles. Scenedesmus obliquus was chosen to be the model organism because it is capable to accumulate large amounts of zinc and because it involves polyphosphate in its detoxification mechanism [20-22].

Zinc is an essential trace metal for all organisms, however it can be toxic when present in high amounts. Exposure of microalgae to sublethal concentrations of $\mathrm{Zn}$ caused inhibition of different vitally important parameters $[21,23]$. Algae can adapt to long lasting elevated $\mathrm{Zn}$ concentrations, most likely through genetical adaptation [24-26]. The cell cycle of microorganisms is very short; in case of S. obliquus it is around $12 \mathrm{~h}$ at $26^{\circ} \mathrm{C}$, therefore the acclimatization can occur during several days or weeks [27]. If the amount of toxic metal ions in the surrounding medium is too high, the algae react with the uptake of the specific ions, finally leading to the deposition of a nontoxic metal compound inside the cells. The uptake of the metal ions takes place in two steps: the first is a rapid physical biosorption onto the cell wall, followed by a slow, energy consuming membrane transport into the cell $[13,14,18,23]$. The first step is due to the fact that in algal cell walls polysaccharides, proteins and polyphosphates are located, which provide anionic sites for binding of positively charged ions like metals [15-17]. The second step is an active bioaccumulation which leads to an enrichment of metals in the cell interior, the cytoplasm, where the toxic ions can be chelated to nonhazardous compounds [28]. In this last step, the algae detoxify their cytoplasm by sequestering the toxic ions in molecules like phytochelatins or polyphosphates [11].

In the investigated genus Scenedesmus, phytochelatins are not involved in the detoxification of $\mathrm{Ni}, \mathrm{Ag}$ or $\mathrm{Zn}$, but phosphates are [22,29]. Phosphates are essential nutrients for these microorganisms and they can be accumulated in the so called polyphosphate bodies [30]. These cellular compartments contain short and long chain polyphosphates (linear polymers of orthophosphate) as the major component, as well as pyrophosphate, orthophosphate, phosphorus (P) and divalent cations like $\mathrm{Ca}$ and $\mathrm{Mg}$ [31,32]. Polyphosphate bodies serve as a storage pool for these essential elements and molecules but are also involved in the detoxification of harmful metals [12]. When metal ions enter the cell, the activity of polyphosphatase is stimulated. This enzyme hydrolyzes polyphosphate into shorter-chain species or orthophosphate, and subsequently the phosphates build complexes with the toxic metals [33]. Also polyphosphate itself can chelate metal ions, leading to a metal/polyphosphate polymer [34,35]. Many toxic metals, like $\mathrm{Pb}, \mathrm{Cu}, \mathrm{Zn}, \mathrm{Al}, \mathrm{Fe}$, $\mathrm{Cd}$ and $\mathrm{Ag}$ were found to be sequestrated in polyphosphate bodies of green algae, including Scenedesmus [19, 35-38].

\section{Materials and Methods}

\subsection{Organisms and Cultures}

The experiments were conducted with living Scenedesmus obliquus (strain 276-1), obtained from the SAG culture collection Göttingen. The algae were cultivated in BG 11 medium starting at $\mathrm{pH} 6$, in a rotary shaker (Infors HT Multitron II, $100 \mathrm{rpm}$ ) at $26^{\circ} \mathrm{C}$ and permanent illumination (FL tubes Gro-Lux 15W, 3500 lx) [39,40]. The media contained $5.3 \mathrm{mg} \mathrm{P} \mathrm{dm}^{-3}$ and different amounts of $\mathrm{Zn}\left(0 \mathrm{mg} \mathrm{Zn} \mathrm{dm}{ }^{-3}, 0.65 \mathrm{mg} \mathrm{Zn} \mathrm{dm}{ }^{-3}\right.$ and $6.53 \mathrm{mg} \mathrm{Zn}$ $\mathrm{dm}^{-3}$ ), added as $\mathrm{ZnSO}_{4} \cdot 7 \mathrm{H}_{2} \mathrm{O}$ (Roth, Karlsruhe). The algae were incubated 4 weeks. After this time, the cells were still living as revealed by their green color using a light microscope.

A hemocytometer (Marienfeld, Lauda-Königshofen) was used to count the cells in the medium.

\subsection{Chemical Analyses}

$10 \mathrm{ml}$ culture were analyzed from the medium with 0.65 $\mathrm{mg} \mathrm{Zn} \mathrm{dm}{ }^{-3}$, containing $4.2 \times 10^{8}$ algal cells and $10 \mathrm{ml}$ from the medium with $6.53 \mathrm{mg} \mathrm{Zn} \mathrm{dm}^{-3}$, containing $1.4 \times$ $10^{8}$ algal cells. The algae were first washed 5 times with demineralized water (Millipore) to remove non-attached molecules and afterwards washed in hydrochloric acid (0.02 M, pH 3) to collect $\mathrm{Zn}$ from the cell wall. Light microscope observations revealed that the algae survived this treatment, indicating that $\mathrm{Zn}$ from inside the cells did not leak out. The obtained $\mathrm{HCl}$ was analyzed via inductively coupled plasma optical emission spectrometry (ICP-OES; Spectro CIROS). In the second step, the algae washed in $\mathrm{HCl}$ were dried at room temperature and weighted. Afterwards, they were digested in concentrated $\mathrm{H}_{2} \mathrm{SO}_{4} / \mathrm{HNO}_{3}$ (nitric acid), mineralized at $250^{\circ} \mathrm{C}$ and finally suspended in demineralized water (Millipore). This solution was analyzed via ICP-OES to detect $\mathrm{Zn}$ in the cells.

All vials were rinsed in $\mathrm{HCl}$ for $24 \mathrm{~h}$ before use to remove adherent molecules. The experiments were run in triplicate.

\subsection{TEM Sample Preparation and (S)TEM Investigations}

To detect the positions of $\mathrm{Zn}$ accumulation in the algal cells, thin sections of cells treated with $6.53 \mathrm{mg} \mathrm{Zn} \mathrm{dm}^{-3}$ (control without $\mathrm{Zn}$ ) were analyzed. The cells were fixed 
for $1 \mathrm{~h}$ in $0.1 \mathrm{M}$ sodium cacodylate buffer containing $2 \%$ glutaraldehyde ( $\mathrm{pH} 7.4)$, then rinsed with the buffer $(\mathrm{pH}$ 7.4) and finally post-fixed for $1 \mathrm{~h}$ in the buffer containing $1 \% \mathrm{OsO}_{4}(\mathrm{pH}$ 7.4). All fixations were done on ice. After fixation, the cells were dehydrated in $30 \%, 50 \%, 75 \%$, $90 \%$, and finally $3 \times 100 \%$ acetone for $20 \mathrm{~min}$ each [41]. After dehydration the cells were immediately embedded in epoxy resin (modified Spurr embedding kit/Serva) [42]. Ultramicrotomy was applied for preparation of TEM samples [43-45]. The blocks of epoxy with embedded cells were trimmed using the high-speed milling system Leica EM-TRIM2 to get a narrow pyramid top of the block. The trimmed blocks were then cut by using the ultramicrotome Leica EM-UC6. To obtain thin sections, an oscillating water-filled diamond knife with a knife angle of $35^{\circ}$ (Diatome, Biel, Switzerland) was used. Approximately 60 to $100 \mathrm{~nm}$ thick slices were prepared at room temperature with a knife speed set to $1 \mathrm{~mm} \cdot \mathrm{s}^{-1}$ at a cleavage angle of $6^{\circ}$. Slices floating in Millipore water were immediately captured on $\mathrm{Cu}$ grids covered with a lacey carbon film. Ultra-pure Millipore water was used for the preparation of our TEM samples.

The thin cell sections were analyzed via bright field (BF) and annular dark filed (ADF) scanning transmission electron microscopy (STEM) imaging combined with analytical X-ray energy-dispersive spectroscopy (XEDS). Different positions inside the cells treated with $\mathrm{Zn}$, as well as at control cells were measured by means of XEDS in order to examine the chemical composition of the material. BF- and ADF-STEM imaging combined with analytical XEDS measurements were carried out in a VG HB501UX microscope. The VG HB501UX is a dedicated STEM instrument operated in ultra-high vacuum at an accelerating voltage of $100 \mathrm{kV}$, and is equipped with a cold field-emission gun (FEG) source, an XEDS system (Thermo Fischer Scientific, Noran System SIX), and an electron energy-loss spectrometer (EELS, Gatan UHV Enfina system). XEDS spectra were recorded in the raster scan mode over a rectangular area of $20 \times 25 \mathrm{~nm}^{2}$. The beam current during acquisition was $0.06 \mathrm{nA}$ for a beam diameter of $0.6 \mathrm{~nm}$ full width at half maximum (FWHM). Selected area electron diffraction (SAED) experiments were performed using Zeiss 912 TEM (Zeiss, Oberkochen, Germany).

\subsection{Analysis via Fluorescence Microscopy}

Dry crystalline zinc phosphate powder (Sigma-Aldrich, No 587583) was investigated in a cuvette by photoluminescence (PL) and photoluminescence excitation (PLE) spectroscopy (FluoroLog, Horiba Yobin Yvon). PLE, in contrast to a fixed excitation wavelength in PL, uses a continuously tunable excitation wavelength and found a broad absorption band in the deep blue and near UV region. Using a specific wavelength in this absorption band
$(370 \mathrm{~nm})$ luminescence in the blue region was detected. Thus an available appropriate filter set (Zeiss No. 49) was used to observe the living cells treated with $6.53 \mathrm{mg}$ $\mathrm{Zn} \mathrm{dm}{ }^{-3}$ and the untreated cells in medium via a fluorescence microscope (Axiovert 200M, Zeiss, Oberkochen, Germany).

\section{Results and Discussion}

\subsection{Zinc Accumulation in the Cells}

Scenedesmus obliquus was cultivated in media containing two different amounts of $\mathrm{Zn}$ in sublethal concentration. To analyze the biosorption of $\mathrm{Zn}$ ions on the cell wall and the accumulation of the metal inside the cells, they were first washed with diluted $\mathrm{HCl}$ to remove adherent molecules. Afterwards, the still living algae were dried and then digested in nitric acid to measure the amount of intracellular $\mathrm{Zn}$. The obtained solutions were analyzed regarding their $\mathrm{Zn}$ content with ICP-OES. These measurements revealed that $S$. obliquus took up the $\mathrm{Zn}$ ions from the media. Most of the metal was accumulated inside the cells, but $\mathrm{Zn}$ was also attached on the cell walls. When the algae were incubated in the medium with $6.53 \mathrm{mg} \mathrm{Zn} \mathrm{dm}^{-3}$, about $90 \%$ of the $\mathrm{Zn}$ was intracellular. These results are according to previous studies with the related species $S$. subspicatus, where about $80 \%$ of the $\mathrm{Zn}$ ions were detected inside the cells [46].

There was also a positive relationship between the metal content in the media and the metal content in the cells. Algae cultivated in medium containing $0.65 \mathrm{mg} \mathrm{Zn}$ $\mathrm{dm}^{-3}$ incorporated $26 \mu \mathrm{g} \mathrm{Zn}$ per $100 \mathrm{mg}$ algae, which is approximately $2 \mu \mathrm{g} \mathrm{Zn}$ per 100 Mio cells. In the algae cultivated in medium containing $6.53 \mathrm{mg} \mathrm{Zn} \mathrm{dm}^{-3}$, the intracellular amount of $\mathrm{Zn}$ was $518 \mu \mathrm{g}$ per $100 \mathrm{mg}$ algae, that is approximately $34 \mu \mathrm{g}$ zinc per 100 Mio cells. Also other authors found a maximum cellular $\mathrm{Zn}$ content of $650 \mu \mathrm{g} / 100 \mathrm{mg}$ algae in the species $S$. subspicatus [46]. Chlorella took up $600 \mu \mathrm{g} \mathrm{Zn} / 100 \mathrm{mg}$ algae at concentration of $\mathrm{Zn}$ ions in the medium of $5 \mathrm{mg} \cdot \mathrm{dm}^{-3}$ [47]. Since $\mathrm{Zn}$ is an essential micronutrient for algae, this metal can be accumulated in relatively high values without killing the organisms compared to other metals like $\mathrm{Hg}$ or $\mathrm{Pb}$ [28].

\subsection{Intracellular Generation of Zinc-Phosphate-Based Nano Needles}

Our chemical findings reveal that $S$. obliquus accumulates $\mathrm{Zn}$ mainly intracellular. STEM/XEDS measurements were performed to detect the site of the $\mathrm{Zn}$ aggregation. The STEM images unambiguously show that the cell wall of the test organism is built up by distinct layers (Figures 1-3). It is known since a long time, that the cell wall of Scenedesmus consists of 3 layers [48]. Gly- 
coproteins are commonly found in the cell walls of green algae and the sugars glucose, mannose and galactose in Scenedesmus particularly [49,50]. Also polyphosphates have been detected there $[17,51]$. These molecules have negatively charged functional groups, which can bind the positively charged $\mathrm{Zn}$ ions. The high $\mathrm{Zn}$ amount did not kill the cells, but caused severe damage, which can be observed in the disorganization of the whole interior. So the somehow disrupted thylakoid membranes (TM) of the chloroplast can be seen in the BF-STEM image of the cells treated with $\mathrm{Zn}$ (Figure 1(a)). In contrast to the untreated cells (Figure 1(b)), also shrinkage of the cell membrane away from the cell wall can be observed. The structural damage of microalgae exposed to sublethal concentration of metals has been investigated by numerous researchers. Severe injury of organelles due to membrane damage was often observed [35,52,53]. In the blue-green alga Anabaena flos-aquae the thylacoid membranes and in the green alga Chlorella the chloroplast appeared to be the primary target $[37,54]$. In S. obliquus loss of cell chloroplasts and deformation of cell membranes were observed after incubation with elevated $\mathrm{Zn}$ concentrations [55]. This is due to the fact, that photosynthetic activity is inhibited by $\mathrm{Zn}$ application to Scenedesmus sp. [21]. The shrinkage of the cell away from the cell wall has also been observed in blue-green algae after treatment with $\mathrm{Cd}$ [54].

In the STEM images of $\mathrm{Zn}$ treated S. obliquus, deposits of material within the cells are clearly recognizable (Figures 1, 2(a) and (b)). Images at higher magnification of these deposits reveal the existence of nano needles with lengths below $100 \mathrm{~nm}$ (Figure 2(b)). Electron diffraction experiments have shown that the nano needles possess an amorphous character, as can be seen from the selected area electron diffraction (SAED) pattern (Figure 2(b), inset). XEDS spectra measured from different positions of the deposits shown in Figures 2(a) and (b) are presented in Figure 2(c) (spectra 1 and 2). According to our investigations, the $\mathrm{Zn} / \mathrm{P}$ at $\%$ ratio measured from the depositions with (position 1) or without (position 2) nano needles is for both cases approximately 1:4. The most pronounced difference is the increased amount of $\mathrm{Mg}$ in the spectra acquired from the deposit positions containing nano needles. In the cell areas outside the deposits no measurable amounts of $\mathrm{Zn}$ or $\mathrm{P}$ could be detected (data not shown).

In addition, the existence of deposits within one cell treated with $\mathrm{Zn}$ with distinctly different appearance was revealed (Figures 3(a)-(c)). Deposits consisting of fine (FS) and coarse (CS) structured material are coexisting within the cell. According to our XEDS experiments (Figure 3(d)), the $\mathrm{Zn} / \mathrm{P}$ at\% ratio for $\mathrm{CS}$ and $\mathrm{FS}$ is $1: 4$ and $2: 3$, respectively, as determined from 50 measurements in total. An increased amount of $\mathrm{Ca}$ in FS compared to CS deposits is unambiguously detected (Figure 3(d)). It is important to mention that CS deposits are present in cells in much higher amount compared to FS deposits. XEDS measurements from several different deposits in cells showed that $\mathrm{Zn}$ and $\mathrm{P}$ are always accumulated together, however there might be differences in their ratios.
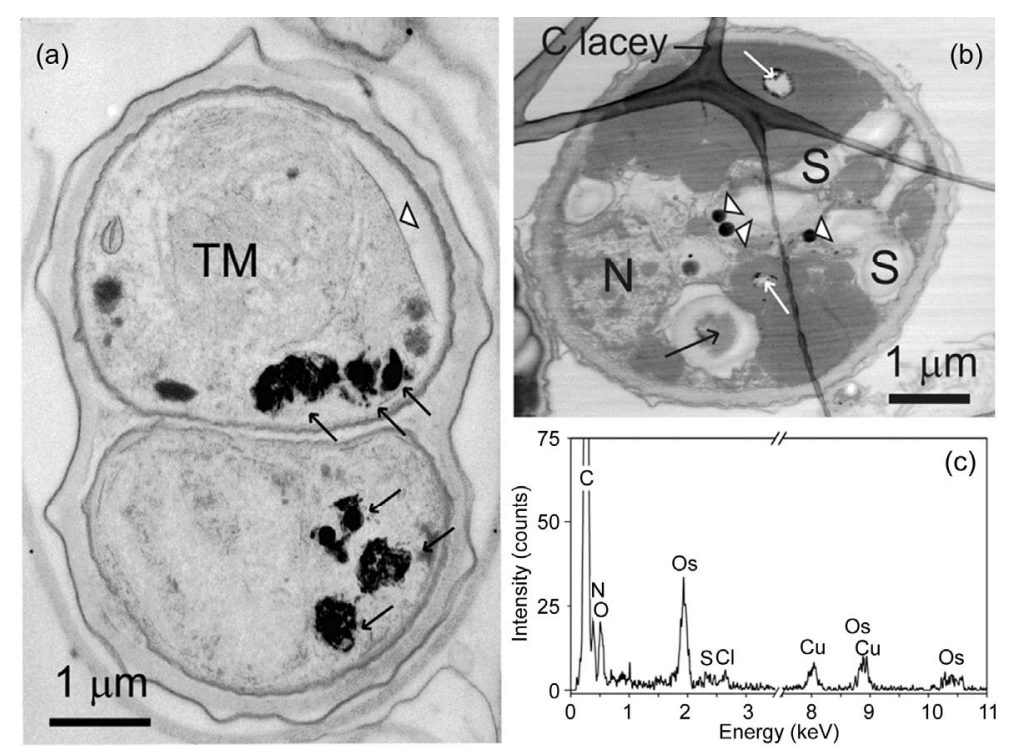

Figure 1. BF-STEM image of (a) Scenedesmus obliquus cells exposed to $6.53 \mathrm{mg} \mathrm{Zn} \mathrm{dm}^{-3}$ for 4 weeks. A number of electrondense deposits are visible (arrows). Shrinkage of the cell away from the cell wall can be observed (white arrow head). BFSTEM image of (b) a control cell. A XEDS spectrum acquired from a cell area (black arrow in Figure (b)) is shown in Figure (c). The Cu signal is from the grid and the Os signal is due to fixation. Holes (white arrows in Figure (b)) are most likely resulting from the preparation and dark round spots (marked with white arrow heads) are aggregations of Os from the fixative. TM: Thylakoid membranes; N: Nucleus; S: Starch grains. 


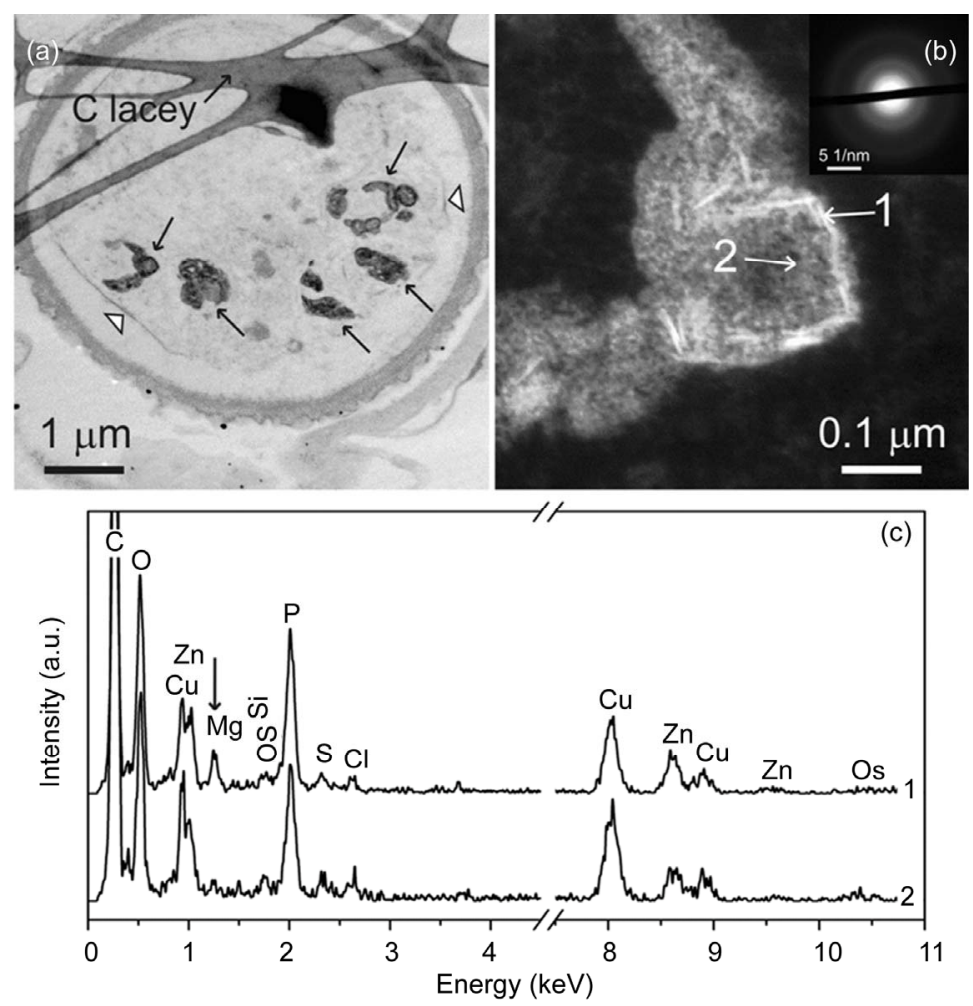

Figure 2. BF-STEM image (a) of Scenedesmus obliquus cells exposed to $6.53 \mathrm{mg} \mathrm{Zn} \mathrm{dm} \mathrm{for}^{-3}$ weeks. The layered structure of the cell wall is clearly recognizable. Shrinkage of the cell away from the cell wall can be observed (white arrow head). Several electron-dense deposits are visible (black arrows). In the ADF-STEM (b) image, the deposits in shape of needles are shown (the leftmost deposit in Figure (a)). Selected area electron diffraction (SAED) pattern from the area including needle-shaped deposits is shown in inset of Figure (b). Positions of XEDS spectra shown in Figure (c) are marked (white arrows) in Figure (b). Note the increased amount of $\mathrm{Mg}$ in the spectrum acquired from the areas containing needle-shaped deposits (spectrum 1 in Figure (c)). The Cu signal is due to the grid.

In control cells without $\mathrm{Zn}$-treatment neither $\mathrm{Zn}$ nor $\mathrm{P}$ could be detected (Figure 1(c)).

These findings are in accordance with the above mentioned detoxification mechanism of green algae, using polyphosphate to sequester toxic ions [19,37]. Polyphosphate, pyrophosphate and orthophosphate, as well as $\mathrm{P}$, $\mathrm{Ca}$ and $\mathrm{Mg}$ are present in polyphosphate bodies of these microorganisms [31,32]. Our findings indicate that the observed deposits refer to $\mathrm{Mg}$ and $\mathrm{Ca}$ containing polyphosphate bodies where the $\mathrm{Zn}$ ions have been sequestered to detoxify the cells. During the detoxification mechanism of the living cells also needle-shaped structures are formed which contain $\mathrm{P}, \mathrm{Zn}$ and $\mathrm{Mg}$.

To our knowledge, this is the first proof of the production of $\mathrm{Zn}$-phosphate-based nano needles by living algae.

In Chlamydomonas acidophila, a green alga, deposits containing $\mathrm{Cd}$ and phosphate were found after $\mathrm{Cd}$ treatment [33]. In bacteria, intracellular electron-dense inclusions were found after treatment with $\mathrm{Pb}$, identified by $\mathrm{XEDS}$ as crystalline $\mathrm{Pb}$-phosphate [56]. A later study on bacterial accumulation of lead via TEM/XEDS could not support these results; the authors found that the $\mathrm{Pb}$-rich polyphosphate bodies are polymers not crystals [34].
According to our results, also in this study $\mathrm{Ca}$ was found to be associated with the $\mathrm{Pb}$-rich polyphosphate bodies. The authors suggest that a part of the $\mathrm{Ca}$ ions normally associated with polyphosphate bodies are exchanged by $\mathrm{Pb}$ ions.

\subsection{Fluorescence of the Zn-Treated Cells}

Crystalline zinc phosphate particles show blue luminescence, as measured by photoluminescence spectroscopy (data not shown). According to that, we investigated the living, Zn-treated cells and untreated controls via fluorescence microscopy. Zn-cultivated cells show a strong fluorescence, mainly on the cell wall or cell membrane and in areas inside the cells close to the cell rim (Figures 4(a) and (b)). In contrast to this finding, the untreated $S$. obliquus cells do not show any fluorescence (Figures 4(c) and (d)). These fluorescence results support the STEM/ XEDS findings in indicating that a Zn-phosphate-based material is generated by the living algae. The involved fluorescent intracellular deposition sites cannot be identified in detail by this method, but we assume that they should be the polyphosphate bodies, known to be 

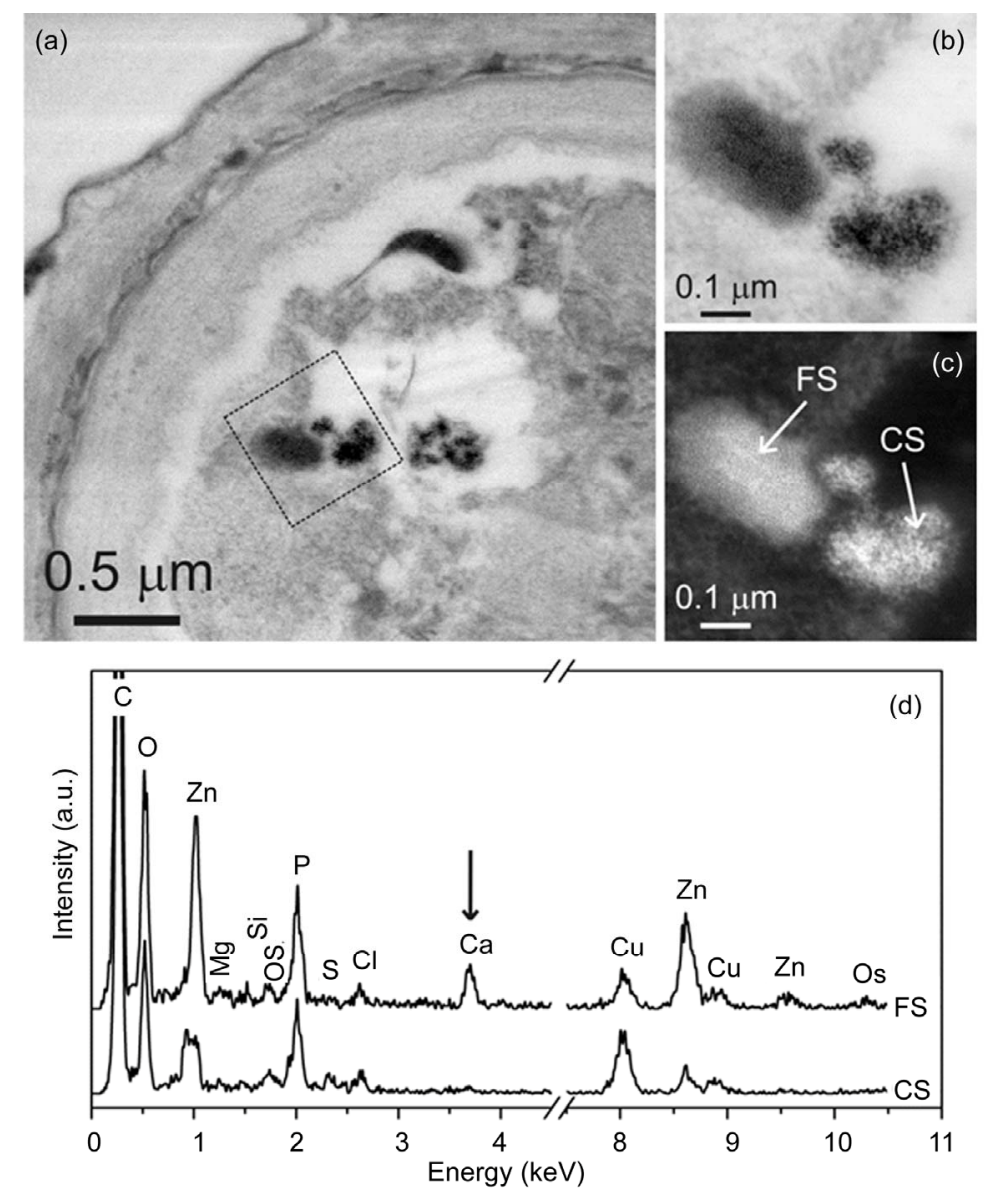

Figure 3. BF-STEM image (a) of Scenedesmus obliquus cells exposed to $6.53 \mathrm{mg} \mathrm{Zn} \mathrm{dm}^{-3}$. BF- (b) and ADF-STEM (c) images showing a magnified area marked in (a). Two types of deposits with different $\mathrm{Zn} / \mathrm{P}$ ratios are present in the cell, appearing as fine structured (FS) and coarse structured (CS) material. XEDS spectra (d) were acquired from positions marked in (c). Note the increased amount of $\mathrm{Ca}$ in the FS deposit. The $\mathrm{Cu}$ signal is due to the grid and the Os signal is from the fixative.
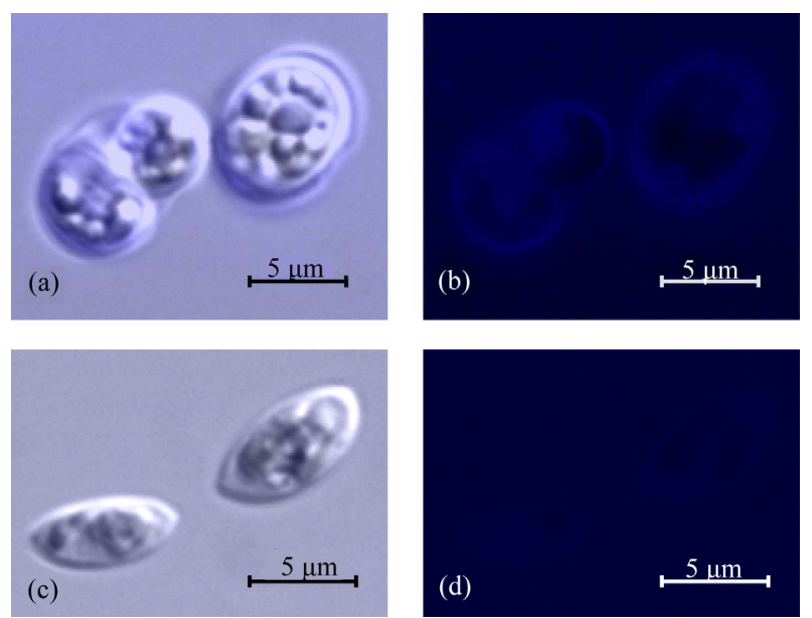

Figure 4. Images of living Scenedesmus obliquus cells observed in a fluorescence microscope. When incubated in Zncontaining medium (a), the cells show blue fluorescence mainly at the cell rim and in compartments inside the cells (b), indicating that a Zn-containing phosphate has been produced. Cells cultivated in a medium without $\mathrm{Zn}$ (c) do not show fluorescence (d). the sequestering place for metals in the detoxification mechanism [19,37]. Formation of a Zn-phosphate-based fluorescent material in living algal cells, namely in or near the cell wall or cell membrane, has not been reported yet. The obtained experimental results can be correlated with the detoxification mechanism reported for green algae. In the first step, toxic metal ions bind on the cell wall of the algae $[13,14]$. In the cell walls of green algae also polyphosphates are located [17,51]. In the next step, some of the metal ions are transported into the cell [18]. In order to detoxify the cell interior, they can build complexes with phosphates $[11,12]$. Our results indicate that the $\mathrm{Zn}$-phosphate complexation takes place directly after the transportation of the metal ions into the cell, resulting in fluorescent particles near to the cell membrane. It is also possible that a part of the $\mathrm{Zn}$ ions keep bounded to the polyphosphate in the cell wall and cell membrane, resulting in the fluorescence of these cellular compartments. This is supported by our ICP-OES measurements, by which a part of the $\mathrm{Zn}$ ions were detected on the cell wall. In the bacterium Citrobacter, cadmium 
phosphate was found on the cell surface after cultivation in Cd- and P-containing medium, also bacteria have negatively charged functional groups on their cell surface [57]. In Chlorella, polyphosphates are located outside the cell membrane and are complexed with divalent metal ions [51].

\section{Conclusions and Outlook}

In summary, we produced Zn-phosphate-based deposits in the shape of nano needles through biomineralization mechanisms in living Scenedesmus obliquus cells. This is the first proof of a structured $\mathrm{Zn}$-phosphate-based nano material produced by living algae. Thus we developed a new experimental protocol for the production of an inorganic functional material using the natural detoxification process of living cells which can be applied also for other substances.

In addition, the $\mathrm{Zn}$-cultivated algae show a strong fluorescence in areas, which most likely refer to the $\mathrm{Zn}$ and $\mathrm{P}$ containing deposits. The fluorescence spectra of these deposits and chlorophyll are different. The fluorescent living cells can be used for the labeling of probes in the biological or medical science, leading to real-time observation, e.g. the feeding of algae eating organisms like sponges (Porifera) [58]. Since Scenedesmus cells show fluorescent behavior in presence of elevated $\mathrm{Zn}$ ion concentration, they could be applied for the rapid testing of this toxic metal by fluorescence microscopy.

In further studies, the produced zinc-phosphate-based material could be doped with e.g. Europium (Eu) or silver (Ag) to change the optical characteristics and enhance the fluorescence behavior of the material $[2,59]$. For this purpose, the algae could be treated with Eu or $\mathrm{Ag}$ ions additional to the $\mathrm{Zn}$ ions. Microalgae can be used for decontamination of wastewater due to their ability of accumulating toxic ions intracellular [37,47].

\section{Acknowledgements}

The financial support of DFG (BI469/15-1) is gratefully acknowledged. The authors thank Michael Schweikert for fluorescent microscopy investigations and critical reading of the manuscript. Stefan Pezold helped with the Scenedesmus experiments and Felix Benz and Miao Yang with photoluminescence analyses.

\section{REFERENCES}

[1] T. Akamatsu and T. Kasuga, "Proton Conductivities of Zinc Phosphate Glass-Derived Hydrogels Controlled by Water Content," Journal of the Electrochemical Society, Vol. 154, No. 2, 2007, pp. 258-262.

[2] B. Yan and X. Xiao, "Hydrothermal Synthesis, Controlled Microstructure, and Photoluminescence of Hydrated $\mathrm{Zn}_{3}\left(\mathrm{PO}_{4}\right)_{2}: \mathrm{Eu}^{3+}$ Nanorods and Nanoparticles," Journal of Nanoparticle Research, Vol. 11, No. 8, 2009,

\section{pp.2125-2135. doi:10.1007/s11051-008-9578-6}

[3] M. Roming, C. Feldmann, Y. S. Avadhut and J. Schmedt auf der Günne, "Characterization of Noncrystalline Nanomaterials: NMR of Zinc Phosphate as a Case Study," Materials Chemistry, Vol. 20, No. 18, 2008, pp. 57875795. doi:10.1021/cm800805f

[4] J. D. Wang, D. Li, J. K. Liu, X. H. Yang, J. L. He and Y. $\mathrm{Lu}$, "One-Step Preparation and Characterization of Zinc Phosphate Nanocrystals with Modified Surface," Soft Nanoscience Letters, Vol. 1, 2011, pp. 81-85. doi: $10.4236 / \mathrm{snl} .2011 .13015$

[5] A. Q. Yuan, S. Liao, Z. F. Tong, J. Wu and Z. Y. Huang, "Synthesis of Nanoparticle Zinc Phosphate Dihydrate by Solid State Reaction at Room Temperature and Its Thermochemical Study," Materials Letters, Vol. 60, No. 17-18, 2006, pp. 2110-2114. doi:10.1016/j.matlet.2005.12.082

[6] P. Parhi, V. Manivannan, S. Kohli and P. McCurdy, "Room Temperature Metathetic Synthesis and Characterization of $\alpha$-Hopeit, $\mathrm{Zn}_{3}\left(\mathrm{PO}_{4}\right)_{2} \cdot 4 \mathrm{H}_{2} \mathrm{O}$," Materials Research Bulletin, Vol. 43, No. 7, 2008, pp. 1836-1841. doi:10.1016/j.materresbull.2007.07.005

[7] S. Yan, W. He, C. Sun, X. Zhang, H. Zhao, Z. Li, W. Zhou, X. Tian, X. Sun and X. Han, "The Biomimetic Synthesis of Zinc Phosphate Nanoparticles," Dyes and Pigments, Vol. 80, No. 2, 2009, pp. 254-258. doi:10.1016/j.dyepig.2008.06.010

[8] W. He, S. Yan, Y. Wang, X. Zhang, W. Zhou, X. Tian, X. Sun and X. Han, "Biomimetic Synthesis of Mesoporous Zinc Phosphate Nanoparticles," Journal of Alloys and Compounds, Vol. 477, No. 1-2, 2009, pp. 657-660. doi:10.1016/j.jallcom.2008.10.136

[9] D. Mandal, M. E. Bolander, D. Mukhopadhyay, G. Sarkar and P. Mukherjee, "The Use of Microorganisms for the Formation of Metal Nanoparticles and their Application" Applied Microbiology and Biotechnology, Vol. 69, No. 5, 2006, pp. 485-492. doi:10.1007/s00253-005-0179-3

[10] F. Natalio, E. Mugnaioli, M. Wiens, X. Wang, H. C. Schröder, M. N. Tahir, W. Tremel, U. Kolb and W. Müller, "Silicatein-mediated Incorporation of Titanium Into Spicules from the Demosponge Suberites domuncula," Cell and Tissue Research, Vol. 339, No. 2, 2010, pp. 429-436. doi:10.1007/s00441-009-0903-x

[11] L. C. Rai, "Heavy Metal Tolerance in Algae," In: J. P. Gaur, Ed., Algal Adaptation to Environmental Stresses, Springer, Heidelberg, 2001, pp. 363-388. doi:10.1007/978-3-642-59491-5

[12] J. D. Keasling, "Regulation of Intracellular Toxic Metals and Other Cations by Hydrolysis of Polyphosphate," The New York Academy of Sciences, Vol. 829, 1997, pp. 242249. doi:10.1111/j.1749-6632.1997.tb48579.x

[13] Y. P. Ting, F. Lawson and I. G. Prince, "Uptake of Cadmium and Zinc by the Alga Chlorella vulgaris: Part 1 . Individual Ion Species," Biotechnology and Bioengineering, Vol. 34, No. 7, 1989, pp. 990-999. doi:10.1002/bit.260340713

[14] K. Knauer, R. Behra and L. Sigg, "Adsorption and Uptake of Copper by the Green Alga Scendesmus subspicatus (Chlorophyta)," Journal of Phycology, Vol. 33, No. 4, 
1997, pp. 596-601. doi:10.1111/j.0022-3646.1997.00596.x

[15] D. R. Crist, R. H. Crist, J. R. Martin and J. R. Watson, "Ion Exchange System in Proton-Metal Reactions with Algal Cell Walls," FEMS Microbiology Reviews, Vol. 14, No. 4, 1994, pp. 309-314. doi:10.1111/j.1574-6976.1994.tb00104.x

[16] E. Kiefer, L. Sigg and P. Schosseler, "Chemical and Spectroscopic Characterization of Alga Surfaces," Environmental Science \& Technology, Vol. 31, No. 3, 1997, pp. 759-764. doi:10.1021/es960415d

[17] T. P. Werner, N. Amrhein and F. M. Freimoser, "Inorganic Polyphosphate Occurs in the Cell Wall of Chlamydomonas reinhardtii and Accumulates during Cytokinesis," BMC Plant Biology, Vol. 7, No. 7, 2007, pp. 51-62. doi:10.1186/1471-2229-7-51

[18] G. W. Garnham, G. A. Codd and G. M. Gadd, "Kinetics of Uptake and Intracellular Location of Cobalt, Manganese and Zinc in the Estuarine Green Alga Chlorella salina," Applied Microbiology and Biotechnology, Vol. 37, No. 2, 1992, pp. 270-276. doi:10.1007/BF00178183

[19] T. E. Jensen, J. W. Rachlin, V. Jani and B. Warkentine, "An X-Ray Energy Dispersive Study of Cellular Compartmentalization of Lead and Zinc in Chlorella saccharophila (Chlorophyta), Navicula incerta and Nitzschia closterium (Bacillariophyta)," Environmental and Experimental Botany, Vol. 22, No. 3, 1982, pp. 319-328. doi:10.1016/0098-8472(82)90024-7

[20] C. M. Monteiro, S. C. Fonseca, P. M. L. Castro and F. X. Malcata, "Toxicity of Cadmium and Zinc on Two Microalgae, Scendesmus obliquus and Desmodesmus pleiomorphus, from Northern Portugal," Journal of Applied Phycology, Vol. 23, No. 23, 2011, pp. 97-103. doi:10.1007/s10811-010-9542-6

[21] B. N. Tripathi and J. P. Gaur, "Physiological Behavior of Scendesmus Sp. During Exposure to Elevated Levels of $\mathrm{Cu}$ and $\mathrm{Zn}$ after Withdrawal of Metal Stress," Protoplasma, Vol. 229, No. 1, 2006, pp. 1-9. doi:10.1007/s00709-006-0196-9

[22] R.-Q. Yu and W.-X. Wang, "Biokinetics of Cadmium, Selenum, and Zinc in Freshwater Alga Scendesmus obliquus Under Different Phosphorus and Nitrogen Conditions and Metal Transfer to Daphnia magna," Environmental Pollution, Vol. 129, No. 3, 2004, pp. 443-456. doi:10.1016/j.envpol.2003.11.013

[23] H. H. Omar, "Bioremoval of Zinc Ions by Scendesmus obliquus and Scendesmus quadricauda and Its Effect on Growth and Metabolism," International Biodeterioration \& Biodegradation, Vol. 50, No. 2, 2002, pp. 95-100. doi:10.1016/S0964-8305(02)00048-3

[24] B. T. A. Muyssen and C. R. Janssen, "Zinc Acclimation and Its Effect on the Zinc Tolerance of Raphidocelis subcapitata and Chlorella vulgaris in Laboratory Experiments," Chemosphere, Vol. 45, No. 4-5, 2001, pp. 507514. doi:10.1016/S0045-6535(01)00047-9

[25] B. N. Tripathi, S. K. Mehta, A. Amar and J. P. Gaur, "Oxidative Stress in Scendesmus Sp. during Short- and Long-Term Exposure to $\mathrm{Cu}^{2+}$ and $\mathrm{Zn}^{2+}$," Chemosphere, Vol. 62, No. 4, 2006, pp. 538-544. doi:10.1016/i.chemosphere.2005.06.031
[26] N. Takamura, F. Kasai and M. M. Watanabe, "Effects of $\mathrm{Cu}, \mathrm{Cd}$ and $\mathrm{Zn}$ on Photosynthesis of Freshwater Benthic Algae," Journal of Applied Phycology, Vol. 1, No. 1, 1989, pp. 39-52. doi:10.1007/BF00003534

[27] V. Cepák, P. Přibyl, M. Vítová and V. Zachleder, “The Nucleocytosolic and Chloroplast Cycle in the Green Chlorococcal Alga Scendesmus obliquus (Chlorophyceae, Chlorococcales) Grown under Various Temperatures," Phycologia, Vol. 46, No. 3, 2007, pp. 263-269.

doi:10.2216/06-39.1

[28] D. Schmitt, A. Müller, Z. Csögör, F. H. Frimmel and C. Posten, "The Adsorption Kinetics of Metal Ions onto Different Microalgae and Siliceous Earth," Water Research, Vol. 35, No. 3, 2001, pp. 779-785. doi:10.1016/S0043-1354(00)00317-1

[29] S. L. Faucheur, F. Schildknecht, R. Behra and L. Sigg, "Thiols in Scendesmus vacuolatus upon Exposure to Metals and Metalloids Aquatic," Aquatic Toxicology, Vol. 80, No. 4, 2006, pp. 355-361. doi:10.1016/j.aquatox.2006.10.002

[30] A. Kornberg, N. N. Rao and D. Ault-Riché, "Inorganic Polyphosphate: A Molecule of Many Functions," Annual Review of Biochemistry, Vol. 68, 1999, pp. 89-125. doi:10.1146/annurev.biochem.68.1.89

[31] Y. Komine, L. L. Eggink, H. Park and J. K. Hoober, "Vacuolar Granules in Chlamydomonas reinhardtii: Polyphosphate and a 70-kDa Polypeptide as Major Components," Planta, Vol. 210, No. 6, 2000, pp. 897-905. doi:10.1007/s004250050695

[32] F. A. Ruiz, N. Marchesini, M. Seufferheld, Govindjee and R. Docampo, "The Polyphosphate Bodies of Chlamydomonas reinhardtii Possess a Proton-Pumping Pyrophosphatase and Are Similar to Acidocalcisomes," The Journal of Biological Chemistry, Vol. 276, 2001, No. 49, pp. 46196-46203. doi:10.1074/jbc.M105268200

[33] K. Nishikawa, Y. Yamakoshi, I. Uemura and N. Tominaga, "Ultrastructural Changes in Chlamydomonas acidophila (Chlorophyta) Included by Heavy Metals and Polyphosphate Metabolism," FEMS Microbiology Ecology, Vol. 44, No. 2, 2003, pp. 253-259. doi:10.1016/S0168-6496(03)00049-7

[34] N. Perdrial, N. Liewig, J.-E. Delphin and F. Elsass, "TEM Evidence for Intracellular Accumulation of Lead by Bacteria in Subsurface Environments," Chemical Geology, Vol. 253, 2008, pp. 196-204.

[35] L. Sicko-Goad and D. Lazinsky, "Quantitive Ultrastructural Changes Associated with Lead-Coupled Luxury Phosphate Uptake and Polyphosphate Utilization," Archives of Environmental Contamination and Toxicology, Vol. 15, No. 6, 1986, pp. 617-627. doi:10.1007/BF01054908

[36] C. Ballan-Dufrançais, C. Marcaillou and C. Amiard-Triquet, "Response of the Phytoplantonic Alga Tetraselmis suecica to Copper and Silver Exposure: Vesicular Metal Bioaccumulation and Lack of Starch Bodies," Biology of the Cell, Vol. 72, 1991, pp. 103-112. doi:10.1016/0248-4900(91)90084-Z

[37] S. L. Wong, L. Nakamoto and J. F. Wainwright, "Identification of Toxic Metals in Affected Algal Cells in As- 
says of Wastewaters," Journal of Applied Phycology, Vol. 6, No. 4, 1994, pp. 405-414. doi:10.1007/BF02182157

[38] W. Zhang and V. Majidi, "Monitoring the Cellular Response of Stichococcus bacillaris to Exposure of Several Different Metals Using in Vivo 31P NMR and Other Spectroscopic Techniques," Environmental Science \& Technology, Vol. 28, No. 9, 1994, pp. 1577-1581. doi: $10.1021 / \mathrm{es} 00058 \mathrm{a} 007$

[39] R. Y. Stanier, R. Kunisawa, M. Mandel and G. CohenBazire, "Purification and Properties of Unicellular BlueGreen Algae (Order Chroococcales)," Bacteriological Reviews, Vol. 35, 1971, pp. 171-205.

[40] R. Rippka and M. Herdman, "Catalogue of Strains. Pasteur Culture Collection of Cyanobacterial Strains in Axenic Culture,” Institut Pasteur, Paris, 1992.

[41] Z. Tukaj, A. Baścik-Remisiewicz, T. Skowroński and C. Tukaj, "Cadmium Effect on the Growth, Photosynthesis, Ultrastructure and Phytochelatin Content of Green Microalga Scendesmus armatus: A Study at Low and Elevated $\mathrm{CO}_{2}$ Concentration," Environmental and Experimental Botany, Vol. 60, No. 3, 2007, pp. 291-299. doi:10.1016/j.envexpbot.2006.12.002

[42] A. R. Spurr, "A Low-Viscosity Resin Embedding Medium for Electron Microscopy," Journal of Ultrastructure Research, Vol. 26, No. 1-2, 1969, pp. 31-43. doi:10.1016/S0022-5320(69)90033-1

[43] N. Reid, "Ultramicrotomy," In: A. M. Glauert, Ed., Practical Methods in Electron Microscopy, North-Holland Publishing Company, Amsterdam, 1975, pp. 215-350.

[44] G. H. Michler and W. Lebek, "Ultramikrotomie, " In: G. H. Michler, Ed., Ultramikrotomie in der Materialforschung, Hanser Verlag, Germany, 2004.

[45] H. K. Hagler, "Ultramicrotomy for Biological Electron Microscopy,” In: J. Kuo, Ed., Electron Microscopy, Humana Press, New Jersey, 2007.

[46] K. Knauer, R. Behra and L. Sigg, "Effects of Free $\mathrm{Cu}^{2+}$ and $\mathrm{Zn}^{2+}$ Ions on Growth and Metal Accumulation in Freshwater Algae," Environmental Toxicology and Chemistry, Vol. 16, No. 2, 1997, pp. 220-229. doi:10.1002/etc. 5620160218

[47] R. Kumar and D. Goyal, "Waste Water Treatment and Metal $\left(\mathrm{Pb}^{2+}, \mathrm{Zn}^{2+}\right)$ Removal by Microalgal Based Stabilization Pond System," Indian Journal of Microbiology, Vol. 50, Supp. 1, 2010, pp. 34-40. doi:10.1007/s12088-010-0063-4

[48] T. Bisalputra and T. E. Weier, "The Cell Wall of Scendesmus quadricauda," American Journal of Botany, Vol. 50, No. 10, 1963, pp. 1011-1019. doi:10.2307/2439909

[49] D. H. Miller, "Cell Wall Chemistry and Ultrastructure of Chlorococcum oleofaciens (Chlorophyceae)," Journal of
Phycology, Vol. 14, No. 2, 1978, pp. 189-194. doi:10.1111/j.1529-8817.1978.tb02447.x

[50] H. Takeda, "Cell Wall Sugars of Some Scendesmus Species," Phytochemistry, Vol. 42, No., 3, 1996, pp. 673-675. doi:10.1016/0031-9422(95)00952-3

[51] J. Sianoudis, A. C. Küsel, A. Mayer, L. H. Grimme and D. Leibfritz, "Distribution of Polyphosphates in Cell-Compartments of Chlorella fusca as Measured by 31P-NMRspectroscopy," Archives of Microbiology, Vol. 144, No., 1, 1986, pp. 48-54. doi:10.1007/BF00454955

[52] L. Sicko-Goad, "A Morphometric Analysis of Algal Response to Low Dose, Short-Term Heavy Metal Exposure," Protoplasma, Vol. 110, No., 2, 1982, pp. 75-86. doi:10.1007/BF01281533

[53] M. A. Smith, "The Effect of Heavy Metals on the Cytoplasmic Fine Structure of Skeletonema costatum (Bacillariophyta)," Protoplasma, Vol. 116, No., 1, 1983, pp. 1423. doi:10.1007/BF01294226

[54] J. W. Rachlin, T. E. Jensen and B. Warkentine, "The Toxicological Response of the Alga Anabaena flos-aquae (Cyanophyceae) to Cadmium," Archives of Environmental Contamination and Toxicology, Vol. 13, No., 1, 1984, pp. 143-151. doi:10.1007/BF01055871

[55] T. Atici, H. Katircioğlu and B. Akm, "Sensitivity of Freshwater Microalgal Strains (Chlorella vulgaris Beijerinck and Scendesmus obliquus (Turpin) Kützing) to Heavy Metals," Fresenius Environmental Bulletin, Vol. 17, No. 3, 2008, pp. 268-274.

[56] H. S. Levinson, I. Mahler, P. Blackwelder and T. Hood, "Lead Resistance and Sensitivity in Staphylococcus aureus," FEMS Microbiology Letters, Vol. 145, No. 3, 1996, pp. 421-425. doi:10.1111/j.1574-6968.1996.tb08610.x

[57] L. E. Macaskie, A. C. R. Dean, A. K. Cheetham, R. J. B. Jakeman and A. J. Skarnulis, "Cadmium Accumulation by a Citrobacter Sp.: The Chemical Nature of the Accumulated Metal Precipitate and Its Location on the Bacterial Cells," Journal of General Microbiology, Vol. 133, 1987, pp. 539-544.

[58] P. E. de Almeida, J. R. M. van Rappard and J. C. Wu, "In Vivo Bioluminescense for Tracking Cell Fate and Function," American Journal of Physiology-Heart and Circulatory Physiology, Vol. 301, No. 3, 2011, pp. 663-671. doi:10.1152/ajpheart.00337.2011

[59] I. Belharouak, H. Aouad, M. Mesnaoui, M. Maazaz, C. Parent, B. Tanguy, P. Gravereau and G. Le Flem, "Crystal Structure and Luminescence Properties of Silver in $\operatorname{AgM}\left(\mathrm{PO}_{3}\right)_{3}(\mathrm{M}=\mathrm{Mg}, \mathrm{Zn}, \mathrm{Ba})$ Polyphosphates," Journal of Solid State Chemistry, Vol. 145, No. 1, 1999, pp. $97-$ 103. doi:10.1006/jssc. 1999.8227 